\title{
Community Structure and Diversity of nirS-type Denitrifying Bacteria in Paddy Soils
}

\author{
Zebin Chen ${ }^{1}$, Xi Gao ${ }^{2}$, Tiyuan Xia ${ }^{1}$, Yuan Su${ }^{3}$, Jiani Liu', Lei Yu ${ }^{4}$, Dingkang Wang ${ }^{1}$, \\ Shengguang $\mathrm{Xu}^{5}$, * \\ ${ }^{1}$ College of Agronomy, Kunming University, Kunming, Yunnan, China \\ ${ }^{2}$ College of Plant Protection, Yunnan Agricultural University, Kunming, Yunnan, China \\ ${ }^{3}$ Key Laboratory of Characteristic Biological Resource Development and Utilization of Colleges and \\ Universities in Yunnan Province, Kunming, Yunnan, China \\ ${ }^{4}$ Yunnan Urban Characteristic Agriculture Engineering Technology Research Center, Kunming, Yunnan, \\ China \\ ${ }^{5}$ Yunnan Institute of Biological Carbon Engineering Research Center, Kunming, Yunnan, China \\ *Corresponding author
}

Keywords: Rice; Soil; Nirs Gene; Denitrifying Bacteria; Diversity.

\begin{abstract}
To understand the community structure and diversity of nirS-type denitrifying bacteria in paddy soil. The nirS gene was used as a molecular marker to construct a clone library of nirS gene in paddy soil. OTU cluster analysis and species taxonomy analysis were performed on the cloned sequences. The 318 valid sequences in the library can be divided into 18 OTUs at a similar level of 97\%, belonging to Proteobacteria, Actinobacteria and Unclassified bacterial groups. Proteobacteria $(69.50 \%)$ is the most dominant group in the library, and there are mainly Gammaproteobacteria (50.00\%), Betaproteobacteria (17.30\%) and Alphaproteobacteria (2.20\%) groups. The Gamma class is the most dominant class in Proteobacteria, and all of them belong to the Pseudomonas group. Most of the nirS gene sequences in paddy soils are consistent with those previously found in soils, sludge and estuaries.
\end{abstract}

\section{Introduction}

Paddy soil is an important part of constructed wetlands, and the biogeochemical cycling processes such as nitrogen accumulation, migration and loss in paddy soils are important factors for the health and sustainable development of paddy field ecosystems [1]. The process of biological nitrification and denitrification is a key process of soil nitrogen transformation, which directly affects the agronomic and environmental issues such as soil nitrogen utilization, nitrate nitrogen leaching, groundwater pollution and greenhouse gas emissions [2]. The dry and wet alternation of paddy fields promotes the occurrence of biological denitrification in paddy soils, which makes the denitrification process an important way for nitrogen loss in paddy fields [3]. In-depth study of key microbial community structure and diversity in soil bio-nitrification and denitrification means great significance for revealing the effect of denitrification on nitrogen transformation of paddy fields and reasonable application of nitrogen fertilizer. At present, many researchers have used the nitrite reductase functional genes (nirS and nirK) which catalyzes restoration of nitrite to nitric oxide as the main molecular markers of denitrifying bacteria to study the diversity and abundance of denitrifying bacterial communities in different habitat soils by denaturing gradient gel electrophoresis, end-labeling restriction fragment length polymorphism, real-time fluorescence quantitative PCR technique. It was found that $3 / 4$ of the denitrifying bacteria were nirS type whose diversity is more abundant than that of nirK type as demonstrated in its more than 80 bacterial genera [4]. On the one hand, during paddy-upland rotation, dry and wet paddy soils alternate, and reduction and oxidation reactions follow in the soil, providing a suitable habitat for denitrifying bacteria and positive 
denitrification [5]. Although there are many reports on the diversity of denitrifying bacteria in the soil, there are few studies on the particular habitat of paddy soil. On the other hand, there is no corresponding relationship between nirS gene and bacterial population, and only some of the microorganisms in the same population may have nirS gene. This means that it is impossible to judge from a phylogenetic relationship whether a certain bacterium is a denitrifying bacteria [6]. Since most of the denitrifying bacteria in nature cannot be cultured at present, it is impossible to systematically study denitrifying bacteria species through traditional pure culture techniques. Therefore, it is also difficult to study the structure of denitrifying bacteria based on 16S rRNA gene [7]. To this end, the nirS gene was used as a molecular marker to construct a nirS genotype denitrifying bacterial clone library for paddy soil, and OTU (cluster operation unit) cluster analysis and species taxonomy analysis were performed on the cloned subsequences. Based on the results of OTU cluster analysis, OTU was analyzed for species diversity index and the sequencing depth was verified. Based on the results of taxonomic analysis, statistical analysis of the community structure was conducted at different classification levels to reveal the community structure and diversity of nirS-type denitrifying bacteria in paddy soils.

\section{Materials and Methods}

\subsection{Soil Sample Collection}

The paddy field was located at the test base of Xiangshi Village, Kunming College, Anning City, Yunnan Province (N24'56'24.85", E102'32'14.45"). The test rice variety was "Dian Kun You No.8 (Yunnan Approval No. 2014013)", and field management was conducted according to the conventional cultivation method of local rice. Paddy soils were collected during the rice maturation period (August 2017). In 200m2 paddy fields, 5 points were randomly selected for surface soil $(0-5 \mathrm{~cm})$ collection. One soil sample was collected at each site, with stones, plant debris removed. The sample was then stored at $4^{\circ} \mathrm{C}$ and DNA was extracted within 24 hours.

\subsection{Soil DNA Extraction}

Omega's Soil Genomic DNA Extraction Kit (Omega D5625-01 Soil DNA Kit) was used to extract the DNA of 5 paddy soil samples. After the extraction was completed, an equal amount of DNA was mixed into 1 sample. The DNA fragment size was determined by $0.8 \%$ agarose gel electrophoresis. The concentration and mass of the DNA were determined using a Nanodrop ND-2000 Ultra-Micro Nucleic Acid Protein Analyzer.

\subsection{PCR amplification of nirS gene}

The nirS gene was amplified using the primer pair cd3aF (5'-GTSAACGTSAAGGARACSGG-3') -R3cd (5'-GASTTCGGRTGSGTCTTGA-3') [8]. Amplification conditions are the same as those described in the literature [8]. The fragment size of the amplified product was detected by $1.0 \%$ agarose gel electrophoresis.

\subsection{Cloning and sequencing of nirS gene}

The PCR amplified products were purified by Qiagen's DNA fragment purification kit (QIAquick PCR Purification Kit), and the purified PCR products were TA cloned and transformed into Escherichia coli. DH5 $\alpha$ by Takara's vector kit (pMD19-T Vector Cloning Kit) to construct nirS gene clone library. A white single colony was picked using blue-white selection. With M13F (5'-GGTAACGCCAGGGTTTTCC-3') and M13R (5'-CAGGAAACAGCTATGACC-3') as primers, positive recombinants containing the target fragment were screened by colony PCR and sent to Shanghai Sunny Biotech Co., Ltd. for sequencing.

\subsection{Analysis of Clone Library}

Uchime software was used to remove the PCR amplification-generated chimera from the original sequence to obtain the effective sequence. The effective sequences were clustered at $97 \%$ similarity 
level using Uparse software to obtain the OTU representative sequence which was then compared with all sequences using the Usearch Global method. Then, an abundance statistical table for each sample at each OTU was obtained. The annotation information of the known most similar species was subjected to Blast aligning. Classification information of each level (phylum, class, order, genus) was obtained through the accession number of the species information. Mothur software was used for species diversity index analysis (Chao index, Ace index, Coverage index, Shannon index and Simpson index).

\section{Results and Analysis}

\subsection{PCR amplification of nirS gene}

Using the DNA of paddy soil samples as a template, PCR amplification with primer cd3aF/R3cd yielded a 400-500 bp fragment of nirS gene. The band in lane is single, neat and bright, and the fragment size is in line with expectations, and consistent with the findings of Throback et al. [9]. The band in gel extraction lane was TA-cloned to construct nirS gene clone library.

\section{2 nirS Gene Clone Library Analysis}

From the nirS gene clone library, 325 white colonies were randomly selected for colony PCR validation, followed by sequencing. A total of 325 original sequences were obtained, and after removing the chimera sequences, 318 valid sequences were obtained. According to the similarity level of $97 \%$, it can be divided into 18 OTUs, with coverage of $98.43 \%$. The dilution curve basically reaches the plateau phase (Figure 1), indicating that the sequencing depth is appropriate, and the constructed nirS gene clone library can represent diversity of nirS gene in paddy soil samples. The library has a Simpson index of 0.20, a Shannon index of 2.02, a Chao1 index of 28.00 and an Ace index of 22.00. A sequence was selected from each of the 18 OTUs as the representative sequence of the OTU to construct a phylogenetic tree (Figure 2). The annotation information of the known most similar species is subjected to Blast aligning to obtain species information of each OTU at different taxonomic levels (phylum, class, order, genus) (Table 1).

Among the 318 valid sequences, 221 sequences and 11 OTUs belong to Alpha (7 sequence, 1 OTU), Beta (55 sequences, 7 OTUs) and Gamma class (159 sequences, 3 OTUs) of Proteobacteria, 7 sequences of Alphaproteobacteria are distributed in Magnetospirillum of Rhodospirillales; 55 sequences of Betaproteobacteria are distributed in Cupriavidus (4 sequence, 1 OTU) of Burkholderiales, Azospira (46 sequences, 5 OUTs) and Dechloromonas (5 sequences, 1 OTU) of Rhodocyclales; 159 sequences and 3 OTUs of Gammaproteobacteria are distributed in Pseudomonas of Pseudomonadales. The 4 sequences, 1 OUT belong to Oryza of the Poales. The 1 sequence and 1 OTU belong to Kocuria of Actinobacteria. In addition, there are still 92 sequences and 5 OTUs whose taxonomic status cannot be determined.

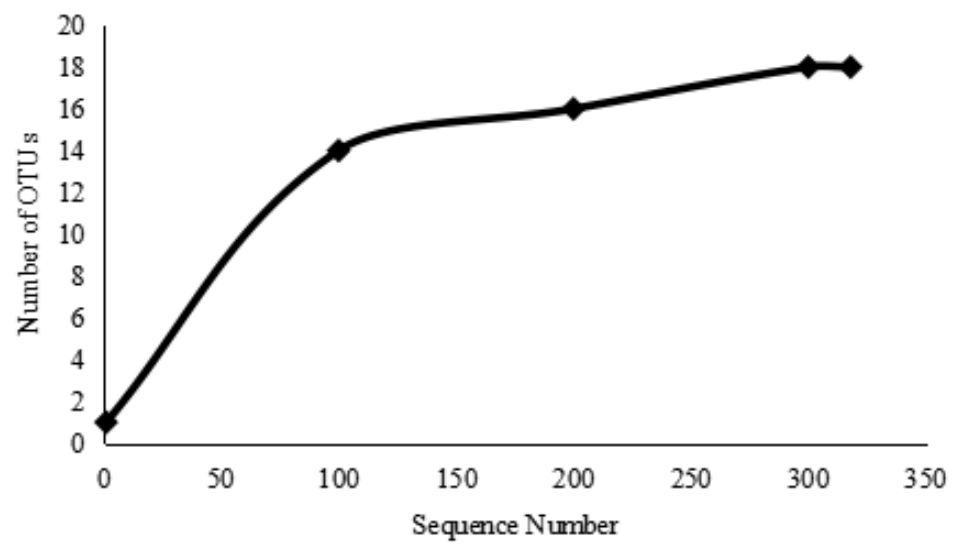

Figure.1 OTUs abundance dilution curve of nirS denitrifying bacteria 


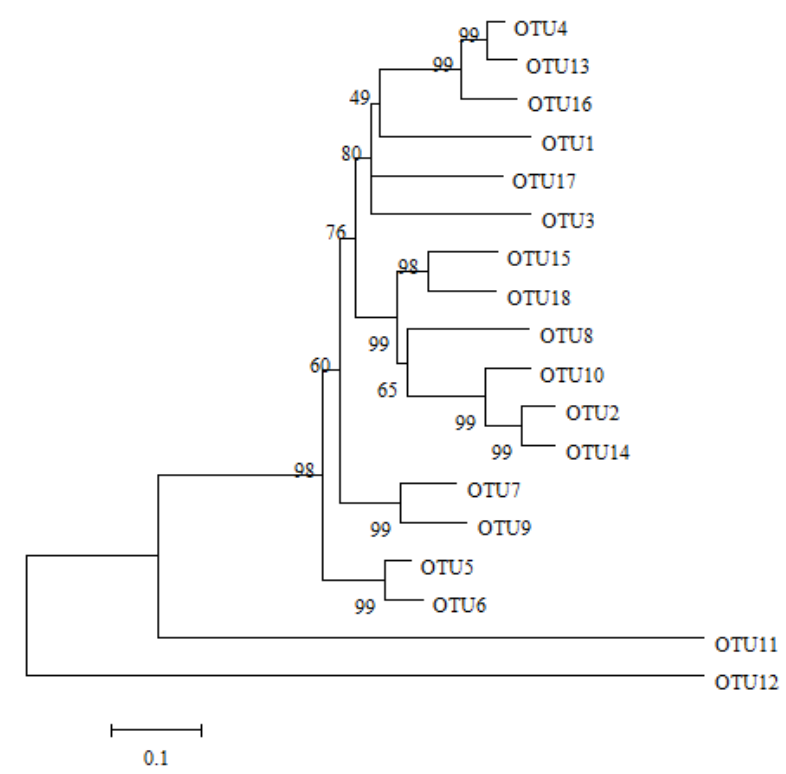

Figure.2 Phylogenetic tree of each OTU representative sequence

Table 1 Species information table based on OTU

\begin{tabular}{|c|c|c|c|c|c|c|c|}
\hline $\begin{array}{c}\text { OUT } \\
\text { name }\end{array}$ & $\begin{array}{c}\text { Sequence } \\
\text { number }\end{array}$ & $\begin{array}{c}\text { Proportion } \\
(\%)\end{array}$ & Phylum & Class & Order & Family & Genus \\
\hline OTU1 & 123 & 38.68 & $\begin{array}{c}\text { Proteoba } \\
\text { cteria }\end{array}$ & $\begin{array}{l}\text { Gammapro } \\
\text { teobacteria }\end{array}$ & $\begin{array}{l}\text { Pseudomo } \\
\text { nadales }\end{array}$ & $\begin{array}{l}\text { Pseudomon } \\
\text { adaceae }\end{array}$ & $\begin{array}{c}\text { Pseudomo } \\
\text { nas }\end{array}$ \\
\hline OTU2 & 46 & 14.47 & - & - & - & - & - \\
\hline OTU3 & 40 & 12.58 & - & - & - & - & - \\
\hline OTU4 & 35 & 11.01 & $\begin{array}{l}\text { Proteoba } \\
\text { cteria }\end{array}$ & $\begin{array}{l}\text { Gammapro } \\
\text { teobacteria }\end{array}$ & $\begin{array}{l}\text { Pseudomo } \\
\text { nadales }\end{array}$ & $\begin{array}{c}\text { Pseudomon } \\
\text { adaceae }\end{array}$ & $\begin{array}{c}\text { Pseudomo } \\
\text { nas }\end{array}$ \\
\hline OTU5 & 9 & 2.83 & $\begin{array}{c}\text { Proteoba } \\
\text { cteria }\end{array}$ & $\begin{array}{c}\text { Betaproteo } \\
\text { bacteria }\end{array}$ & $\begin{array}{l}\text { Rhodocyc } \\
\text { lales }\end{array}$ & $\begin{array}{l}\text { Rhodocycl } \\
\text { aceae }\end{array}$ & Azospira \\
\hline OTU6 & 8 & 2.52 & $\begin{array}{l}\text { Proteoba } \\
\text { cteria }\end{array}$ & $\begin{array}{c}\text { Betaproteo } \\
\text { bacteria }\end{array}$ & $\begin{array}{l}\text { Rhodocyc } \\
\text { lales }\end{array}$ & $\begin{array}{l}\text { Rhodocycl } \\
\text { aceae }\end{array}$ & Azospira \\
\hline OTU7 & 20 & 6.29 & $\begin{array}{c}\text { Proteoba } \\
\text { cteria }\end{array}$ & $\begin{array}{c}\text { Betaproteo } \\
\text { bacteria }\end{array}$ & $\begin{array}{l}\text { Rhodocyc } \\
\text { lales }\end{array}$ & $\begin{array}{l}\text { Rhodocycl } \\
\text { aceae }\end{array}$ & Azospira \\
\hline OTU8 & 8 & 2.52 & $\begin{array}{l}\text { Proteoba } \\
\text { cteria }\end{array}$ & $\begin{array}{c}\text { Betaproteo } \\
\text { bacteria }\end{array}$ & $\begin{array}{l}\text { Rhodocyc } \\
\text { lales }\end{array}$ & $\begin{array}{l}\text { Rhodocycl } \\
\text { aceae }\end{array}$ & Azospira \\
\hline OTU9 & 5 & 1.57 & $\begin{array}{c}\text { Proteoba } \\
\text { cteria }\end{array}$ & $\begin{array}{c}\text { Betaproteo } \\
\text { bacteria }\end{array}$ & $\begin{array}{l}\text { Rhodocyc } \\
\text { lales }\end{array}$ & $\begin{array}{l}\text { Rhodocycl } \\
\text { aceae }\end{array}$ & $\begin{array}{c}\text { Dechloro } \\
\text { monas }\end{array}$ \\
\hline OTU10 & 4 & 1.26 & - & - & - & - & - \\
\hline OTU11 & 1 & 0.31 & - & - & - & - & - \\
\hline OTU12 & 4 & 1.26 & $\begin{array}{l}\text { Streptop } \\
\text { hyta }\end{array}$ & Liliopsida & Poales & Poaceae & Oryza \\
\hline OTU13 & 4 & 1.26 & $\begin{array}{l}\text { Proteoba } \\
\text { cteria }\end{array}$ & $\begin{array}{c}\text { Betaproteo } \\
\text { bacteria }\end{array}$ & $\begin{array}{l}\text { Burkholde } \\
\text { riales }\end{array}$ & $\begin{array}{c}\text { Burkholder } \\
\text { iaceae }\end{array}$ & $\begin{array}{c}\text { Cupriavid } \\
\text { us }\end{array}$ \\
\hline OTU14 & 1 & 0.31 & - & - & - & - & - \\
\hline OTU15 & 1 & 0.31 & $\begin{array}{l}\text { Proteoba } \\
\text { cteria }\end{array}$ & $\begin{array}{c}\text { Betaproteo } \\
\text { bacteria }\end{array}$ & $\begin{array}{l}\text { Rhodocyc } \\
\text { lales }\end{array}$ & $\begin{array}{l}\text { Rhodocycl } \\
\text { aceae }\end{array}$ & Azospira \\
\hline OTU16 & 1 & 0.31 & $\begin{array}{c}\text { Actinoba } \\
\text { cteria }\end{array}$ & $\begin{array}{c}\text { Actinobact } \\
\text { eria }\end{array}$ & $\begin{array}{l}\text { Micrococc } \\
\text { ales }\end{array}$ & $\begin{array}{c}\text { Micrococc } \\
\text { aceae }\end{array}$ & Kocuria \\
\hline OTU17 & 1 & 0.31 & $\begin{array}{c}\text { Proteoba } \\
\text { cteria }\end{array}$ & $\begin{array}{l}\text { Gammapro } \\
\text { teobacteria }\end{array}$ & $\begin{array}{l}\text { Pseudomo } \\
\text { nadales }\end{array}$ & $\begin{array}{c}\text { Pseudomon } \\
\text { adaceae }\end{array}$ & $\begin{array}{c}\text { Pseudomo } \\
\text { nas }\end{array}$ \\
\hline OTU18 & 7 & 2.20 & $\begin{array}{c}\text { Proteoba } \\
\text { cteria }\end{array}$ & $\begin{array}{c}\text { Alphaprote } \\
\text { obacteria }\end{array}$ & $\begin{array}{l}\text { Rhodospir } \\
\text { illales }\end{array}$ & $\begin{array}{l}\text { Rhodospiri } \\
\text { llaceae }\end{array}$ & $\begin{array}{c}\text { Magnetos } \\
\text { pirillum }\end{array}$ \\
\hline
\end{tabular}

From the statistical graph of relative abundance of nirS genes at different classification levels, it can be seen that Proteobacteria is the most dominant group in the nirS gene library, accounting for the highest proportion of $69.50 \%$. It mainly includes Gammaproteobacteria accounting for 50.00\%, 
Betaproteobacteria accounting for $17.30 \%$, and Alphaproteobacteria accounting for $2.20 \%$. It can be seen that Gamma class is the most dominant group in Proteobacteria. The Gammaproteobacteria accounting for $50.00 \%$ belongs to Pseudomonas group in Pseudomonadales, Betaproteobacteria accounting for $17.30 \%$ is distributed in Cupriavidus (1.26\%) of Burkholderiales, Azospira (14.47\%) and Dechloromonas (1.57\%) of Rhodocyclales; Alphaproteobacteria accounting for $2.20 \%$ is distributed in Magnetospirillum (2.20\%) of Rhodospirillales. The taxonomic status of the sequence accounting for $28.93 \%$ has not yet been determined. Streptophyta accounting for $1.26 \%$ is distributed in Oryza (1.26\%) of the Poales; Actinobacteria accounting for $0.31 \%$ is distributed in Kocuria (0.31\%) of Micrococcales.

\section{Discussion}

Through the cluster and species taxonomy analysis of 318 valid clone sub-sequences in the constructed nirS gene clone library, the community structure and diversity of nirS-type denitrifying bacteria in paddy soil were further recognized. The constructed library showed abundant diversity of nirS gene. The results of Yin Chang et al. [10] showed that nirS-type denitrifying bacteria in black soil consisted of Proteobacteria's Alpha, Beta and Gamma classes and some uncultured bacterial groups. This is similar to the results of this study. This study suggests that the nirS-type denitrifying bacterial population in the paddy soil includes the most dominant Proteobacteria group, very few Actinobacteria group and some unclassified bacterial groups. Where, Gammaproteobacteria accounts for the most, while Alphaproteobacteria accounts for the least. However, it has been reported that Alphaproteobacteria accounts for the largest proportion in the estuarine environment [11]. This may be because different ecological environments cause different colony abundances. In this study, Proteobacteria is the most dominant phylum in the nirS gene library, accounting for the highest proportion of $69.50 \%$, which is consistent with the results of Snaidr et al. [12] on the diversity of denitrifying bacteria in sludge. The dominant group in the sludge is also Proteobacteria group. It has been reported in the literature that Proteobacteria group is dominant in abundance, one characteristic of microbial community structure in river environments [13]. Gammaproteobacteria accounting for $50.00 \%$ belongs to Pseudomonas group of Pseudomonadales. This group is considered as typical aerobic or facultative aerobic heterotrophic denitrifying bacteria with organic carbon sources as energy sources, which is one of the largest denitrifying bacteria groups reported so far. Many species below this genus have been used as model strains for denitrification process study [14]. It has been reported that Pseudomonas can remove nitrate nitrogen from water by denitrification. Such denitrification activity is negatively related to the dissolved oxygen content in water [15]. The Betaproteobacteria accounting for $\mathbf{1 7 . 3 0 \%}$ is distributed in Cupriavidus of Burkholderiales, Azospira and Dechloromonas of Rhodocyclales. In the denitrifying bacteria gene library established by Zhang Yan et al. [16], Cupriavidus, Azospira and Dechloromonas groups were also detected. According to reports, Betaproteobacteria group plays an important role in removal of nutrients, formation of floc structures and degradation of organic matter [16]. The Alphaproteobacteria accounting for $2.20 \%$ is distributed in Magnetospirillum group. The study of this group as a denitrifying bacteria group is rarely reported. In 2012, Bo Tao [17] identified 2 denitrifying components of nitrate reductase and nitrite reductase in the magnetotactic bacteria model strain MS-1, confirming that there was an independent denitrification system in this population. The Actinobacteria accounting for $0.31 \%$ is distributed in Kocuria of Micrococcales. It has been reported that the colony belongs to chemoheterotrophic bacteria colony, which can produce acid from fructose and xylose, and also ferment other carbohydrate for acid production [18]. Through Blast aligning of annotation information of known most similar species, it was found that taxonomic status of 28.93\% (92 sequences, 5 OTUs) sequences could not be determined, indicating that this part of nirS gene sequence was a new group not found in previous studies. Similarly, Zhang Yan [16] also discovered an unclassified bacterial population accounting for $17.00 \%$ in the study of denitrifying microorganisms in sludge. Seen from the phylogenetic tree of each OTU representative sequence (Figure 3), OTU2 (46), OTU14 (1) and OTU10 (4) are clustered into one branch, and they are closest to the branches of OTU8. Presumably, the 51 sequences may be closely related genera of Azospira. 
The distance between OTU3 (40) and OTU17 is the shortest. Presumably, sequence of OTU3 may be closely related genus of Pseudomonas. The distance between OTU11 (1) and OTU12 is the shortest. Presumably, sequence of OTU11 may be closely related genus of Oryza. The 5 sequences of OTU11 and OTU12 belong to16S rDNA sequence of rice Chloroplasts, and therefore are the farthest from the branches of other sequences. Presumably, that plant residues in soil samples have not been sufficiently removed, resulting in mixture of trace amounts of rice plant DNA in the extracted soil genomic DNA. In previous studies of similar species, similar "DNA contamination" phenomena were also found [19].

\section{Acknowledgements}

This paper is supported by National Natural Science Foundation of China (41361056); Joint Special Fundamental Research of Local Universities in Yunnan Province (2017FH001-041); Talent Introduction Program of Kunming University (YJL14005); Key Disciplines (Ecology) Project of Yunnan Education Department (05000511311); Open Fund Project of Key Laboratory of Characteristic Biological Resources Development and Utilization in Yunnan Province (GXKZ201716).

\section{References}

[1] Zhao Weiye, Zhu Bo, Wang Zhihui, et al. Nitrification of calcareous purple soil and response of denitrifying microorganisms to different nitrogen sources[J]. Acta Pedologica Sinica, 2018, 55(2): 479-489.

[2] Ji Yang, Yu Haiyang, Ralf C, et al. Effect of Coupling Measures of Intermission Irrigation and Controlled Release Fertilizer Application on Soil Microbial Community Abundance in Rice-wheat Rotation System[J]. Ecology and Environment, 2017, 26(10): 1696-1703.

[3] Zhou Rong, Zhu Guibing, Zhou Leiliu, et al. Spatial-temporal distribution and community structure analysis of anaerobic methane-oxidizing bacteria for denitrification in paddy soil[J]. Acta Scientiae Circumstantiae, 2015, 35(3): 729-737.

[4] Yin Chang. Response of N2O production and reduction in farmland soil and related functional microorganisms to temperature and fertilization[D]. Chinese Academy of Agricultural Sciences, 2017.

[5] Xie Kaizhi, Xu Peizhi, Jiang Ruiping, et al. Application of organic and inorganic fertilizers to increase soil transformation nitrogen-related microbial abundance and rice yield in cold-waterlogged fields[J]. Journal of Plant Nutrition and Fertilizer, 2016, 22(5): 1267 -1277.

[6] Liu Ruojun, He Jizheng, Zhang Limei. Nitrification / denitrification and Changes of Functional Microorganisms under Different Soil Moisture in Paddy Soils[J]. Environmental Science, 2014, 1(11): 4275-4283.

[7] Wang Peixuan, Xu Yan, Song Yana. Effects of transgenic rice straw returning on nitrification and denitrification soil microbial community[J]. Chinese Journal of Eco-Agriculture, 2018, 26(1): 8-15.

[8] Azziz G, Monza J, Etchebehere C, et al. nirS and nirK type denitrifier communities are differentially affected by soil type, rice cultivar and water management[J]. European Journal of Soil Biology, 2017(78): 20-28.

[9] Throback I N, Enwall K, Jarvis A, et al. Reassessing PCR primers targeting nirS, nirK and nosZ genes for community surveys of denitrifying bacteria with DGGE[J]. Fems Microbiology Ecology, 2004, 49(3): 401-417.

[10] Yin Chang, Fan Fenliang, Li Zhaojun, et al. Effects of long-term application of organic and inorganic fertilizers on population structure and abundance of nirS-type denitrifying bacteria in black soil[J]. Environmental Science, 2012, 33(11): 3967 -3975. 
[11] Yoshida M, Ishii S, Otsuka S, et al. Temporal shifts in diversity and quantity of nirS and nirK in a rice paddy field soil[J]. Soil Biology \& Biochemistry, 2015, 41(10): 2044-2051.

[12] Snaidr J, Amann R, Huber I, et al. Phylogenetic analysis and in situ identification of bacteria in activated sludge[J]. Appl Environ Microbiol, 1997, 63(7): 2884-2896.

[13] Yue Zeying. Bacterial community characteristics and its response to environmental factors in sediment-laden rivers [D]. Xi'an University of Technology, 2015.

[14] Fang Fang, Wang Shumei, Feng Cuijie, et al. Denitrifying bacterial community structure in a composite biofilm-activated sludge reactor under aerobic conditions[J]. Chinese Journal of Ecology, 2011, 30(3): 430-437.

[15] Liang Hulian, Guo Xiaoya, Liu Yang, et al. Microbial community structure analysis of four kinds of nitrifying bacteria enriched cultures based on high-throughput sequencing [J]. Microbiology China, 2017, 44(9): 2112-2119.

[16] Zhang Yan, Yan Shengyong, Zhang Yanqing, et al. Application of PCR-DGGE and Cloning Techniques to Analyze Biofilm Bacteria in Tandem Accretion Bed System [J]. Journal of Beijing University of Technology, 2013, 39(1): 122-130.

[17] Bo Tao. Study on the effect of Magnetospirillum magneticum AMB-1 denitrification metabolism and DNA damage repair system on the synthesis of magnetosomes and its genetic stability [D]. Shandong University, 2012.

[18] Guan Tongwei. Diversity and polyphasic taxonomy of actinomycetes in Lop Nur Salt Lake in Xinjiang [D]. Sichuan Agricultural University, 2012.

[19] Qiu Fubin, Liu Lin, Song Wei. PCR amplification and sequencing of ribosomal small subunit DNA of ginseng organelles[J]. Biotechnology China, 2008(1): 124-127. 